\title{
TECHNICAL ANALYSIS OF DIFFERENT POWER RATING OF AGRICULTURAL TRACTORS IN LIBYA
}

\author{
S. M. younis ${ }^{1 *}$, G. E. M. Nasr ${ }^{2}$, M. M. A. Esseid ${ }^{3}$
}

\section{ABSTRACT}

The aim of this investigation was to find out the optimum tractor power requirement under Libyan agricultural conditions in order to suggest the most suitable tractor power for the majority of Libyan farmers. A comparison was carried out between two tractor power level, 47HP and $75 H P$, for the sake of locating the optimum power that could provide the farmer' with his basic needs for a progressive mechanized operations under specific condition. The tested parameters were drawbar pull, slip percentage, fuel consumption, and maneuverability. The lowest wheel slip percentage was recorded with tractor $47 \mathrm{HP}$ when operating all implements except with the chisel plough 2st pass. Also it was clear that, there was significance different between the mechanical elements with different types of power that the lowest wheel slip percent was obtained by chisel plough first pass and land leveler. It was clear that the tractor $75 H P$ when currying different equipment, that the fuel consumption (measured in $l / h$ ) was higher than the tractor $47 \mathrm{HP}$. The actual field capacity of tractor 75HP was significantly higher than that of tractor $47 H P$ with different implements. Also it was evident that the field efficiency when tractor 47HP is executing the 1st pass with chisel plough was higher than the efficiency with implemented. Also it was evident that the efficiency when tractor 75hp is executing others the chisel plough 2nd pass is higher than the efficiency with other implements. Also it was evident that the efficiency of tractor 47HP is greater than the efficiency of tractor $75 H P$ in deferent operations.

\footnotetext{
${ }^{1}$ Prof., Agric. Eng. Dept., Fac. of Agric., Cairo Univ., Giza, Egypt.

${ }^{2}$ Prof., Agric. Eng. Dept., and Vice Dean for Education and Students affairs Fac. of Agric., Cairo Univ., Giza, Egypt.

${ }^{3}$ M. Sc. Student, Agric. Eng. Dept., Fac. of Agric., Cairo Univ., Giza, Egypt.
} 
The higher efficiency obtained by 47HP, where the lowest efficiency was recorded with disc plough. The 47HP rating tractor provided the higher value of efficiency in all the tested operations. Consequently it is more suitable for the tested mechanized operations.

Keyword: Agricultural tractors, mouldboard plough, chisel plough, disc plough and leveler.

\section{INTRODUCTION}

T $\mathrm{n}$ recent years the agricultural sector has increasingly focused on the ability of farmers to make their available resources as productive as Lossible within market, environmental and other regulatory constraints. In this regard, labour and machinery are important input factors dominating all other cost categories and, potentially, it should be possible to make reductions in machinery costs by adapting and operating the machines optimally within the boundaries of the actual needs arising from farm size, crop plan, and other factors.

Since the developing countries mostly depend on agricultural practices as the main source in private and national incomes, this will be activated by the use of agricultural mechanized operations. Producers are searching for ways to improve machinery fuel economy in order to minimize input costs and remain competitive in today's global agricultural economy. According to the deficit of petroleum products through few future decades, therefore, it's necessary to rationalize the fuel consumption in agricultural practices such as ploughing operation. The present state of agricultural conditions in Libya characterized by midget plots, and narrow agricultural lanes present two main restrictions in mechanization, namely:

1- The low operating speed of the implement (due to short trips in the field)

2- The limited width of implement (due to narrow lanes or paths).

Tillage is known to have a wide range of effects on soil physical properties, especially moisture availability and conductivity. There have been contrasts in results from tillage research due to different soils, climate and experimental designs. These inconsistencies further necessitate a review of all tillage systems as practiced across most parts 
of the world in order to be able to make quantitative assessment of their needs (Johnson and Jose, 2011).

Hanna (1978) mentioned that there were many ploughs used in Egypt such as chisel, mouldboard, disc and rotary ploughs. They also added that the prevailed tillage system in Egypt are; chiseling tillage by using chisel plough, turning tillage by using mouldboard or disc plough, and mixed tillage by using rotary plough.

Hadas (1997) reported that tillage implements exert an external stress the soil, causing it to fail in several different modes (brittle, shear, plastic, compressive), depending on initial soil conditions (bulk density, water content and existing fractures or cracks). The extent, mode and fineness of soil failure determine the quality of the soil structure produced. Although tillage implements have been in use for generations, their mode of operation in soil is only partly understood. The operation mode of tined implements, in contrast to that of mouldboard ploughs, is theoretically predictable with respect to the energy required and the form of the general failure planes produced.

Historically, the efficient use of energy in agriculture did not have a high priority. However, taking into consideration the diminishing supply of fossil fuels, efficiency was taken more seriously. Fuel is the source of energy for the tractor providing for the performance of work and propelling the tractor to overcome implement draught. Fuel consumption generally is a function of the tractor size, tillage implement, tractor/implement match, depth and speed of operation, and the soil type and soil physical condition (Smith, 1993).

Soil-working operations in conventional farming systems involving the use of the tractor are some of the operations that incur the highest levels of energy cost. The sustainability of such systems requires a strictly controlled management of resources leading to a significant reduction of crop-production costs derived from savings in fuel consumption (Serrano et al., 2007).

Sahu and Raheman (2008) reported that the matching and performance prediction of a tractor implement system involves many decision-making 
processes that depend on a host of factors. Some factors, like tractor, tire and implement specifications; soil conditions, etc. are inherent to the tractor-implement system and cannot be altered or controlled. Others, like hitching characteristics (mounted, semi-mounted and trailed), operating conditions (depth and speed of operation), types of field operation (primary or secondary), etc. can be adjusted for the purpose of achieving maximum performance. A correct matching of tractorimplement system would result in decreased power losses, improved efficiency of operation, reduced operating costs and optimum utilization of capital on fixed costs.

Due to the global demand for food items, the increased costs of mechanization on the farm and the current disposition of financial institutions towards agricultural credits, it became very critical for existing farmers, farm managers and agricultural investors to make informed decisions based on figures, and improve the management of mechanization operations. Bamigboye and Ojolo (2002) opine that the cost of operating farm tractors can be reduced if the right tractor is used for the right operation as well as manufacturers' recommended annual use.

The formulation of appropriate agricultural mechanization strategy that provides the basic conditions for largely self-sustaining developments might not be effective without critical assessment of the economic implication of the requisite investment. Profit making is critical to the success and sustainability of any business venture and it is pertinent that agricultural mechanization follow the same trend for a meaningful economic and environmental impact. The tractor is the main unit of farm machinery and ensures better quality of farm operations, timely completion of farm activities, better management supervision and dignity of labour (Sandeep and Kumar, 2006).

The aim of this investigation was to recommend the optimum tractor power requirement under Libyan agricultural conditions in order to suggest the most suitable tractor power for the majority of Libyan farmers. This will definitely be a great help to the Libyan agricultural sectors for the selection and the manufacturing the most needed level of power. 


\section{MATERIAL AND METHODS}

A field experiment was carried out during growing season of 2012 on a clay and sand loamy soils at the Experimental Center, Faculty of Agriculture, Tripoli University. Three different primary tillage equipment, chisel, mouldboard and disc were used, in addition to land leveler in this work was also used for land leveling.

These implements were chosen according to the following criteria:

- Very popular among farmers as primary and secondary tillage equipment.

- Important implement within the strategy for reduced cultivations.

- Well represented within the local farm machinery industry.

Two tractors of different powers $47 \mathrm{HP}$ and $75 \mathrm{HP}$ were used to execute the common mechanized operations in Libya .These different powers were compared technically.

\section{1- Materials}

The two tractors 47HP and 75HP were used in the present study and their specifications are.

1. Tractor Massey Ferguson ( Elgedh) 275 - type made in Libya four cylinders, four strokes, two wheel drive, diesel engine $55 \mathrm{~kW}$ (75HP) weight $2800 \mathrm{~kg}$.

2. Tractor Massey Ferguson (Elgedh) 240- type made in Libya four cylinders, four strokes, two wheel drive, diesel engine (47 HP)weight5334kg.

To evaluate the different capacities of these tractors the following implements were used:

a. Primary tillage equipment: three different types and models of ploughs were used namely; chisel, mouldboard and disc ploughs and the four forward speeds (slow gears) which were estimated by measuring the time spent through a travel of 100 meters long, to suit the above mentioned powers and the models are shown in table1.

b. Mounted chisel ploughs.

c. Secondary tillage equipment

d. Land leveler: It is used for land leveling. 
Table 1 Specifications of different implements used in the present work

\begin{tabular}{|l|c|c|c|c|}
\hline Specification & Chisel plough & Disc plough & Mouldboard plough & Land Leveler \\
\hline Type & mounted & Mounted & mounted & \\
\hline No. of tines & 7 & 7 & 3 & \\
\hline Category & II & II & II & I,II \\
\hline Type of plate & standard & Standard & standard & Standard \\
\hline Blades arrangement & 3front, 4rear & 7 bottoms & 4 bottoms & \\
\hline Working width, cm & 175 & 150 & 120 & 180 \\
\hline Total weight, $\mathrm{kg}$ & 300 & 400 & 400 & 250 \\
\hline
\end{tabular}

\section{2- Methods}

a. Experimental procedure

The main experiment was carried out during season of 2012, at the Experimental Center, College of Agriculture, Tripoli University.in order to determine the tractor power requirement for the common operations practiced in Libyan agriculture. To determine the tractors speeds: running each of the two different tractors at a distance of $100 \mathrm{~m}$ on the paved ground outside the field experiment and measuring the time with different gears to choose the working forward speed of all tractors. Speed was calculated by dividing the distance over the time of ploughing of mechanical unit at the full fuel using the following equation:

$\mathrm{V}=(\mathrm{D} / \mathrm{T}) \times 3.6 \quad, \quad \mathrm{~km} / \mathrm{h}$

Where:

V: Speed $(\mathrm{km} / \mathrm{h})$.

D: Distance (m).

T: Time (s).

3.6= coefficient for changing from $\mathrm{m} / \mathrm{s}$ to $\mathrm{km} / \mathrm{h}$.

Soil leveling was carried out to give the soil surface a suitable uniformity (of approximate 1/1000) at the four forward speeds (slow gears).

The evaluation of the tested tractors was done by taking into consideration the following indicators:

a. The theoretical field capacity (TFC)

The theoretical field capacity (TFC) was calculated by using the following formula (Younis, 1995): 


$$
\mathrm{TFC}=\frac{\mathrm{W} \times \mathrm{S} \times 1000}{10000}=0.1 \times \mathrm{W} \times \mathrm{S}, \quad \text { ha } / \mathrm{h} .
$$

Where:

$\mathrm{W}=$ working width of implement, $(\mathrm{m})$

$\mathrm{S}=$ average working forward speed, $(\mathrm{km} / \mathrm{h})$

b. The actual field capacity (AFC)

The actual field capacity (AFC) was calculated as follows (Nasr, 1985)

$\mathrm{AFC}=\frac{1}{\text { actual total time in hours required per hectare }}, \quad$ ha $/ \mathrm{h}$.

a. The field efficiency $\left(\eta_{\mathrm{f}}\right)$

The field efficiency $\left(\eta_{\mathrm{f}}\right)$ was calculated by using the following formula (Nasr, 1985):

Fuel consumption (FC)

$$
\eta_{\mathrm{f}} \%=\frac{\mathrm{AFC}}{\mathrm{TFC}} \times 100
$$

The fuel consumption was experimentally determined using a designed and locally made apparatus. This apparatus consisted of a graduated transparent plastic bottle attached to the inlet of the injection pump trough plastic hose fixed in the bottle rubber stopper. To use apparatus, the bottle was filled with a certain amount of fuel, and then closed inverted and connected of the inlet of the injection pump.

$$
\mathrm{FC}=\left(\mathrm{Q}_{\mathrm{f}} / \mathrm{A}_{\mathrm{Tt}}\right) \times 3.6 \quad, \quad \mathrm{~L} / \mathrm{h}
$$

Where:

$\mathrm{Q}_{\mathrm{f}}=$ amount of fuel consumed in one treatment $(\mathrm{ml})$

$\mathrm{A}_{\mathrm{Tt}}=$ actual total Time (s)

c. brake horsepower requirement per unit area

Estimation of requirement brake horsepower (B HP) to operate each machine was carried out by accurately measuring the decrease in fuel level in the fuel tank immediately after executing each operation.

The required energy was calculated by using the following formula:

Where:

$$
\text { B HP }=\left(f_{c} \times \frac{1}{60 X 60}\right) \times \rho_{f} \times \text { L. C. V } \times 427 \times \eta_{\text {th }} \times \eta_{m} \times \frac{1}{75}
$$

$\mathrm{f}_{\mathrm{c}}=$ fuel consumption, lit/h. 
$\rho_{\mathrm{f}}=$ density of fuel, $\mathrm{kg} / \mathrm{l}$ ( for solar fuel $0.85 \mathrm{~kg} / \mathrm{lit}$ )

L.C.V. = lower calorific value of fuel, in $\mathrm{kCal} / \mathrm{kg}$ (average L.C.V. of solar fuel is $10000 \mathrm{Cal} / \mathrm{kg}$ )

$427=$ thermo-mechanical equivalent, $\mathrm{kg} \cdot \mathrm{m} / \mathrm{kCal}$.

$\eta_{\mathrm{th}}=$ thermal efficiency of the engine (considered to be $40 \%$ for diesel engines)

$\eta_{m}=$ mechanical efficiency of the engine (considered to be $80 \%$ for diesel engines)

e- The slip percentage of the tractor rear wheels

The slip percentage ( $\mathrm{S} \%$ ) was determined by using the following formula :

$$
\mathrm{S} \%=\frac{\mathrm{L}_{1}-\mathrm{L}_{2}}{\mathrm{~L}_{1}} \times 100
$$

$\mathrm{L}_{1}$ : advance per 10 wheel revaluations with no load, $\mathrm{m}$

$\mathrm{L}_{2}$ : advance per 10 wheel revaluations with load, $\mathrm{m}$

\section{RESULTS AND DISCUSSION}

The field experiments were conducted in heavy texture soil exceeding (35\%) clay, defined as clay and clay loam soil.

The results and discussion will be presented in two parts as follow:

1- The performance of different tractor power levels when carrying out the most important agricultural operations under Libyan conditions.

2- The field efficiency and actual field capacity for different working units.

The performance of different tractor power when carrying out the most important agricultural operations under Libyan conditions:

The performance of farm tractors can be expressed in many ways. The criterion which best describes the performance depends largely upon the intended use of tractors. This part will study the ability of different tractor powers for carrying the Libyan agricultural operation.

Wheel slip

From Fig. 1 it was revealed that the percent of wheel slip when tractor $47 \mathrm{HP}$ was executing the 2 nd pass with chisel plough is higher than the 
slip present with others implements. Also the statistical analysis showed significance difference between tractors power. The percent of wheel slip when tractor $75 \mathrm{HP}$ was executing the disc plough was the highest among other operation. While, the lowest wheel slip percentage was recorded with tractor 47HP when carrying all operations except with chisel plough 2nd pass. Also, it was clear that there was significant difference between the mechanical elements with different types of power that the lowest wheel slip percent was obtained by chisel plough first pass and land leveler. This is due to the fact that the soil becomes looser and less compaction thus allowing more tractor wheels easily slip with increasing of tractor power.

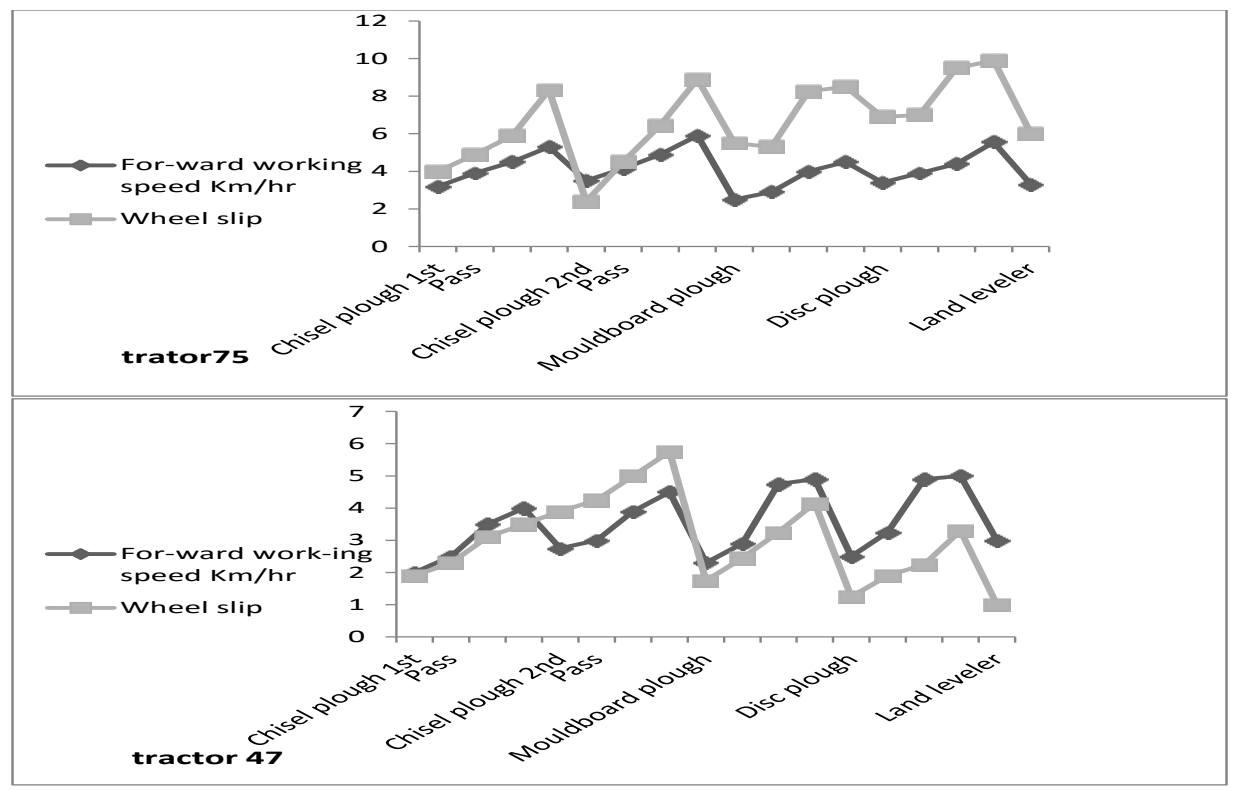

Impliment

Fig. 1 Wheel slips percentage for the two tractors

Comparison between different agricultural working units according to some performance parameter

From the obtained data, presented in Tables 2, 3 and Fig. 2 it is clear that the tractor $75 \mathrm{HP}$ when operating different equipment, the fuel 
consumption (measured in $1 / \mathrm{h}$ per different work width) was higher than the tractor 47HP. Also Table 4 revealed that there was significant difference between tractor powers and their interaction and superiority was found with tractor 47HP. Regard to interaction superiority was recorded with tractor $47 \mathrm{HP}$ when currying land leveler. Where, there was no significant difference between different equipment except with land leveler as presented in Table1. The arrangement of equipment according to the average fuel consumption of tractor $75 \mathrm{HP}$ was found to be in the following descending order: mouldboard plough>disc plough> chisel plough 2nd pass >chisel plough 1st pass > land leveler.

The arrangement of equipment according to the average fuel consumption of tractor 47HP was found to be in the following descending order: Chisel plough 1st pass> chisel plough 2nd pass> mouldboard plough $>$ disc plough $>$ land leveler.

Table 2 Effect of mechanical elements on performing different soil tillage operations using two levels of power

\begin{tabular}{|l|c|c|c|c|}
\hline Treatment & $\begin{array}{c}\text { Wheel } \\
\text { slip\% }\end{array}$ & $\begin{array}{c}\text { Fuel } \\
\text { consumption } \\
\text { l/h }\end{array}$ & $\begin{array}{c}\text { Actual } \\
\text { field ha/h }\end{array}$ & $\begin{array}{c}\text { Estimated } \\
\text { power kW }\end{array}$ \\
\hline 47HPXChisel 1st pass & $2.700 \mathrm{e}$ & $5.288 \mathrm{bc}$ & $1.100 \mathrm{e}$ & $22.612 \mathrm{~b}$ \\
\hline $\begin{array}{l}\text { 47HPXChisel plough } \\
\text { 2nd pass }\end{array}$ & $4.725 \mathrm{~d}$ & $4.863 \mathrm{~cd}$ & $1.263 \mathrm{~cd}$ & $24.400 \mathrm{~b}$ \\
\hline $\begin{array}{l}\text { 47HPXMouldboard } \\
\text { plough }\end{array}$ & $2.900 \mathrm{e}$ & $4.863 \mathrm{~cd}$ & $0.900 \mathrm{f}$ & $21.655 \mathrm{~b}$ \\
\hline 47HPX Disc plough & $2.175 \mathrm{e}$ & $4.288 \mathrm{~d}$ & $1.083 \mathrm{e}$ & $39.183 \mathrm{a}$ \\
\hline 47HPXLand leveler & $2.088 \mathrm{e}$ & $1.263 \mathrm{e}$ & $1.375 \mathrm{bc}$ & $19.192 \mathrm{~b}$ \\
\hline 75HPXChisel 1st pass & $5.778 \mathrm{~cd}$ & $7.900 \mathrm{a}$ & $1.338 \mathrm{c}$ & $36.037 \mathrm{ab}$ \\
\hline $\begin{array}{l}\text { 75HPXChisel plough } \\
\text { 2nd pass }\end{array}$ & $5.563 \mathrm{~cd}$ & $7.925 \mathrm{a}$ & $1.493 \mathrm{ab}$ & $36.182 \mathrm{ab}$ \\
\hline $\begin{array}{l}\text { 75HPXMouldboard } \\
\text { plough }\end{array}$ & $6.888 \mathrm{~b}$ & $8.413 \mathrm{a}$ & $0.735 \mathrm{~g}$ & $36.700 \mathrm{ab}$ \\
\hline 75HPX Disc plough & $8.325 \mathrm{a}$ & $8.050 \mathrm{a}$ & $1.148 \mathrm{de}$ & $36.950 \mathrm{ab}$ \\
\hline 75HPXLand leveler & $6.588 \mathrm{bc}$ & $5.743 \mathrm{~b}$ & $1.513 \mathrm{a}$ & $26.475 \mathrm{~b}$ \\
\hline
\end{tabular}

* Means with similar letters in columns are not significantly different $(\mathrm{P}>0.05)$ 
Table 3 Effect of mechanical elements on tractors performance during tillage operations:

\begin{tabular}{|l|c|c|c|c|}
\hline Treatment & $\begin{array}{c}\text { Wheel } \\
\text { slip }\end{array}$ & $\begin{array}{c}\text { Fuel consumption } \\
1 / \mathrm{h}\end{array}$ & $\begin{array}{c}\text { Actual } \\
\text { field ha/h }\end{array}$ & $\begin{array}{c}\text { Estimated } \\
\text { power } \mathrm{kW}\end{array}$ \\
\hline $\begin{array}{l}\text { Chisel plough } \\
\text { 1st Pass }\end{array}$ & $4.239 \mathrm{~b}$ & $6.594 \mathrm{a}$ & $1.219 \mathrm{~b}$ & $29.325 \mathrm{a}$ \\
\hline $\begin{array}{l}\text { Chisel plough } \\
\text { 2nd Pass }\end{array}$ & $5.144 \mathrm{a}$ & $6.394 \mathrm{a}$ & $1.378 \mathrm{a}$ & $30.291 \mathrm{a}$ \\
\hline $\begin{array}{l}\text { Mouldboard } \\
\text { plough }\end{array}$ & $4.894 \mathrm{ab}$ & $6.638 \mathrm{a}$ & $0.818 \mathrm{~d}$ & $29.178 \mathrm{a}$ \\
\hline Disc plough & $5.250 \mathrm{a}$ & $6.169 \mathrm{a}$ & $1.115 \mathrm{c}$ & $58.566 \mathrm{a}$ \\
\hline Land leveler & $4.338 \mathrm{~b}$ & $3.503 \mathrm{~b}$ & $1.444 \mathrm{a}$ & $22.834 \mathrm{a}$ \\
\hline
\end{tabular}

* Means with similar letters in columns are not significantly different $(\mathrm{P}>0.05)$

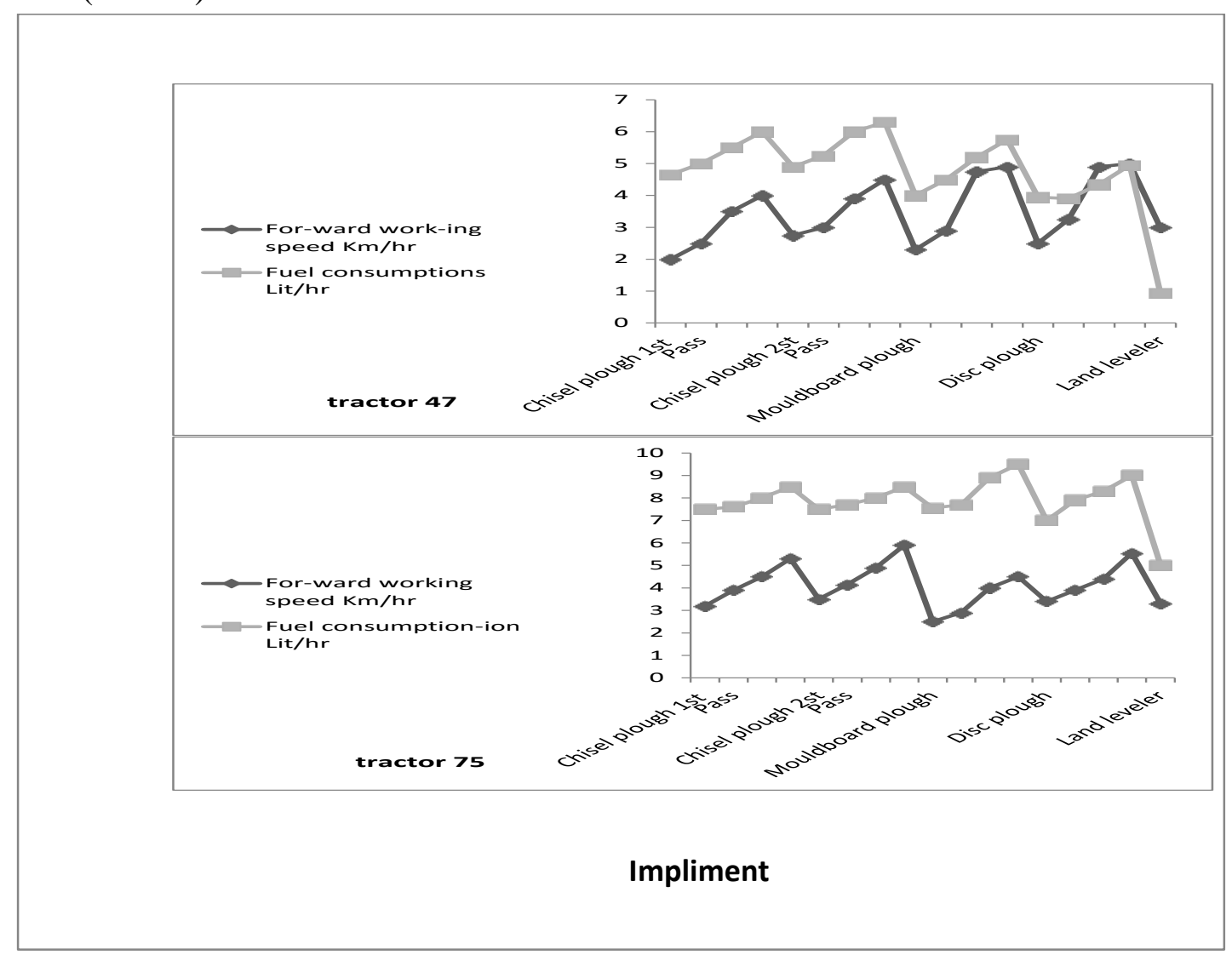

Fig. 2: Fuel consumption for the two tractors, $1 / \mathrm{h}$ 
Actual field capacity:

From the results shown in Tables 2 and 3 and Fig. 3 it is evident that the performance data of actual field capacity was affected by tractors power levels. Tractor $75 \mathrm{HP}$ was significantly higher than that of tractor $47 \mathrm{HP}$ with different implements. In addition, interaction between tractor power levels and mechanical equipments was significantly differed, where the highest actual field capacity was obtained with tractor 75HP when operating land leveler.

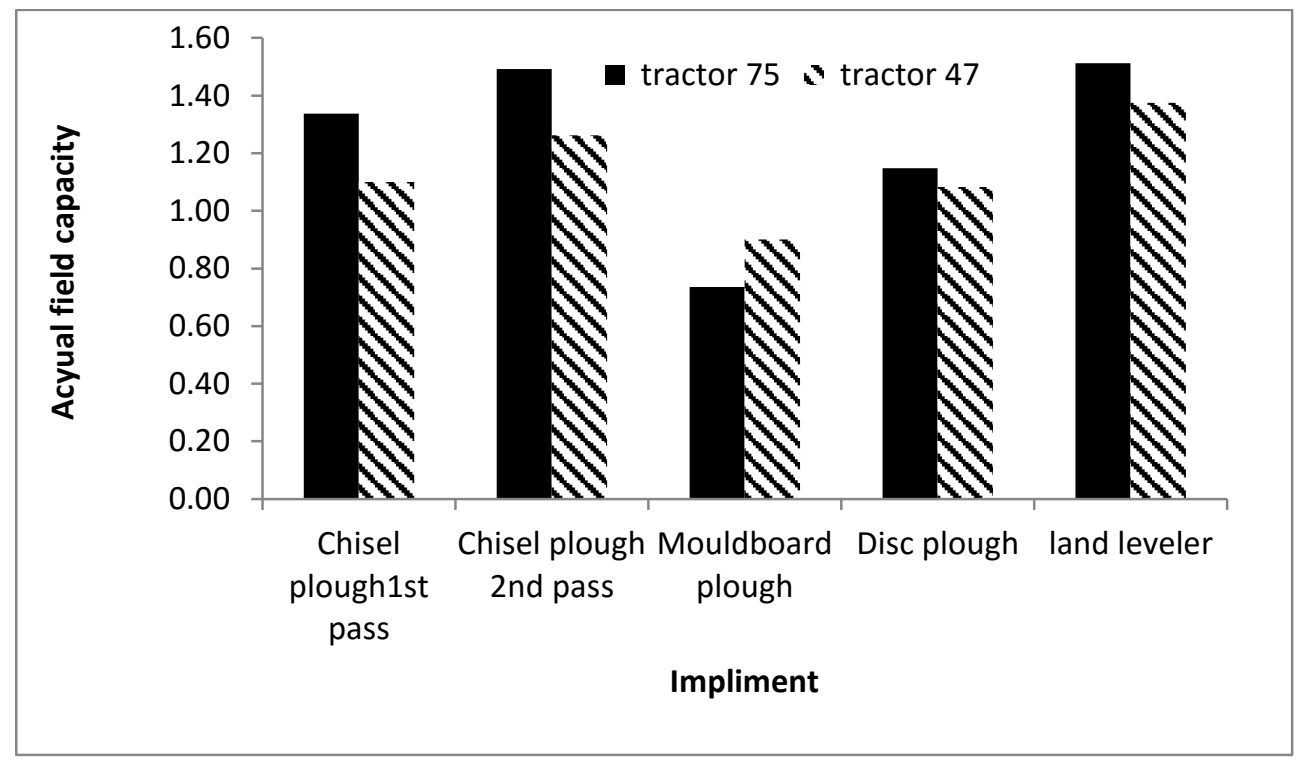

Fig. 3: Actual field capacity of tractors during executing field operations.

Estimated brake HP consumption

From the obtained data, presented in Tables 2, 3 and Fig. 4, it is clear that the brake horsepower required for operating different equipment was found to be higher for tractor $75 \mathrm{HP}$ than the tractor 47HP. There was no significant difference between mechanical implements and tractor power levels. The lowest value of estimated brake horse power was recorded with tractor 47HP when carrying all implements except with disc plough, while the lowest value of estimated brake horse power was recorded with 
tractor 75HP when carrying land leveling by land leveler. It is obvious that increasing of depth cause a considerable increase in draught.

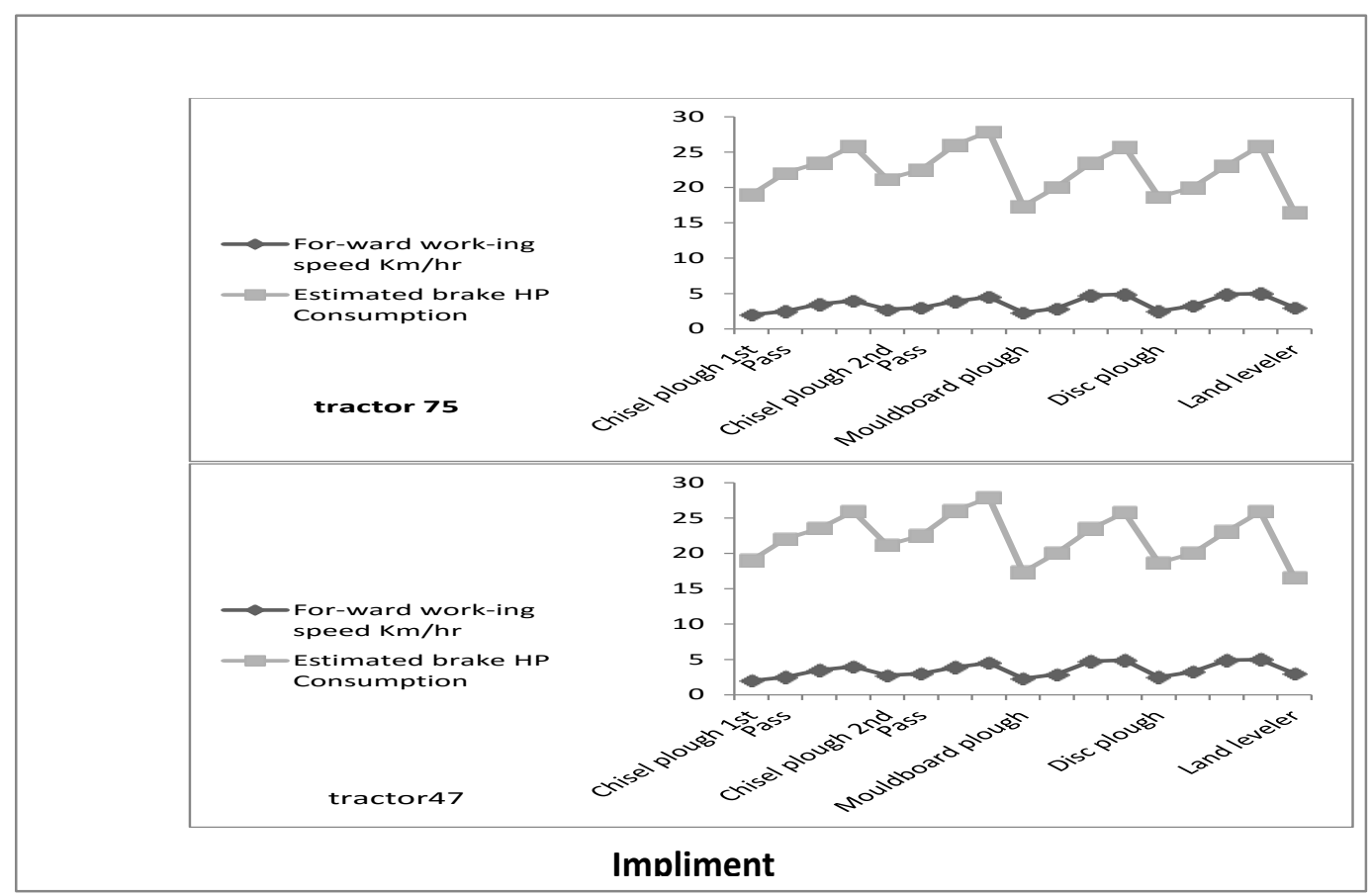

Fig. 4: Estimated of requirement brake HP from the two tractors during executing field operations

The field efficiency for different working units:

The following Tables 4 and 5 present the experimental data measured and calculated during performing different soil tillage operations using the two levels of power. Analysis of the obtained data was based upon one criterion which reflects the effect and contribution of the farm mechanization implements on the performance of tractors types.

The overall efficiency was chosen to help in selecting the suitable power level of the tractor during performing tillage operations.

From Tables 4, 5 and Fig. 5, it is evident that the efficiency when tractor $47 \mathrm{HP}$ was executing the 1 st pass with chisel plough was higher than the 
efficiency with other implements. Also it is evident that the efficiency when tractor $75 \mathrm{HP}$ was executing 2 nd pass with chisel plough was higher than the efficiency with other implements. Generally the efficiency of tractor 47HP was higher than the efficiency of tractor 75HP during deferent operations. Analysis of variance indicated that, there was significant difference between all treatments. The higher efficiency obtained by tractor 47HP, where the lowest efficiency was recorded with disc plough.

Regarding to the interaction between mechanical implement and tractor power level, the higher efficiency was recorded when the tractor 47HP with the chisel plough 2nd pass, and the chisel plough 1st pass, that might be due to the higher percentage of wheel slip with tractor 75HP when operating chisel plough in the second pass and soil capturing more pulverizing loosely. The 47HP rating tractor provided the higher value of efficiency in all the tested operations.

Consequently it was more suitable for the tested mechanized operations.

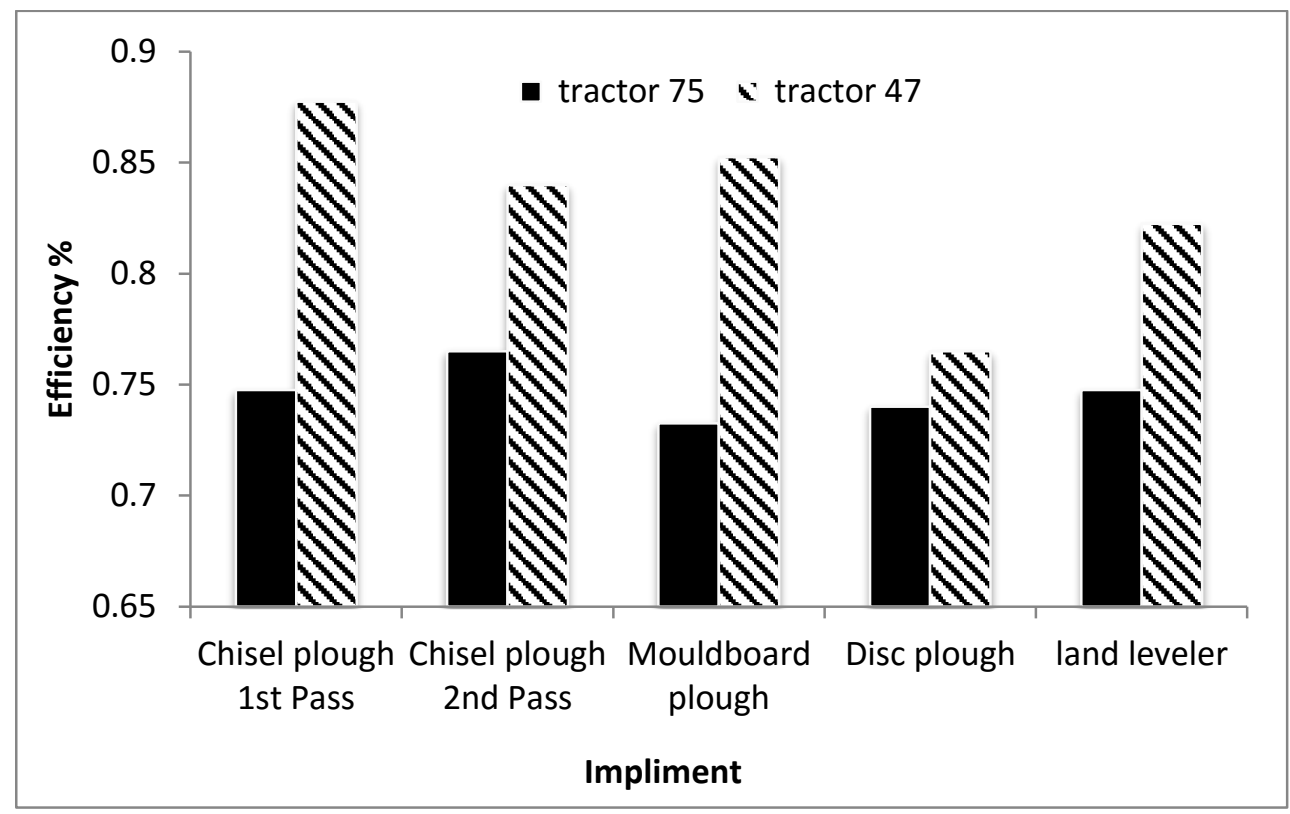

Fig. 5: Field efficiency of the two tractors power during field operations. 
Table 4 the effect of mechanical elements on field efficiency

\begin{tabular}{|l|c|c|c|}
\hline Treatment & Th. Fc & A. F. C. & $\eta \%$ \\
\hline Chisel plough 1st Pass & $1.515 \mathrm{c}$ & $1.281 \mathrm{~b}$ & $0.824 \mathrm{a}$ \\
\hline Chisel plough 2nd Pass & $1.708 \mathrm{~b}$ & $1.378 \mathrm{ab}$ & $0.803 \mathrm{ab}$ \\
\hline Mouldboard plough & $1.035 \mathrm{~d}$ & $0.818 \mathrm{~d}$ & $0.793 \mathrm{ab}$ \\
\hline Disc plough & $1.477 \mathrm{c}$ & $1.115 \mathrm{c}$ & $0.753 \mathrm{~b}$ \\
\hline Land leveler & $1.826 \mathrm{a}$ & $1.444 \mathrm{a}$ & $0.785 \mathrm{ab}$ \\
\hline
\end{tabular}

* Means with similar letters in columns are not significantly different $(\mathbf{P}>0.05)$

Table 5 Effect of mechanical elements on efficiency of two levels of tractor power

\begin{tabular}{|l|c|c|c|}
\hline Treatment & Th.FC & A. F. C. & $\eta \%$ \\
\hline 75HPXChisel 1st pass & $1.770 \mathrm{~b}$ & $1.338 \mathrm{bc}$ & $0.748 \mathrm{~cd}$ \\
\hline 75HPXChisel plough 2nd pass & $1.933 \mathrm{a}$ & $1.493 \mathrm{ab}$ & $0.765 \mathrm{bcd}$ \\
\hline 75HPXMouldboard plough & $1.005 \mathrm{f}$ & $0.735 \mathrm{f}$ & $0.733 \mathrm{~d}$ \\
\hline 75HPX Disc plough & $1.545 \mathrm{~cd}$ & $1.148 \mathrm{de}$ & $0.740 \mathrm{~d}$ \\
\hline 75HPXLand leveler & $1.998 \mathrm{a}$ & $1.513 \mathrm{a}$ & $0.748 \mathrm{~cd}$ \\
\hline 47HPXChisel 1st pass & $1.260 \mathrm{e}$ & $1.225 \mathrm{cde}$ & $0.900 \mathrm{a}$ \\
\hline 47HPXChisel plough 2nd pass & $1.483 \mathrm{~d}$ & $1.263 \mathrm{~cd}$ & $0.840 \mathrm{ab}$ \\
\hline 47HPXMouldboard plough & $1.065 \mathrm{f}$ & $0.900 \mathrm{f}$ & $0.853 \mathrm{a}$ \\
\hline 47HPX Disc plough & $1.408 \mathrm{~d}$ & $1.083 \mathrm{e}$ & $0.765 \mathrm{bcd}$ \\
\hline 47HPXLand leveler & $1.655 \mathrm{bc}$ & $1.375 \mathrm{abc}$ & $0.823 \mathrm{abc}$ \\
\hline
\end{tabular}

* Means with similar letters in columns are not significantly different $(\mathbf{P}>0.05)$ 


\section{CONCLUSION AND RECOMMENDATION}

It was found that the tractor 75HP consumed greater amount of fuel than the tractor 47HP, whereas the actual field capacity of tractor $75 \mathrm{HP}$ was significantly higher than that of tractor 47HP with different implements. Also it was evident that the efficiency when tractor 47HP was executing the 1 st pass with chisel plough was higher than the efficiency with others implemented. Therefore, the overall efficiency was chosen to help in selecting the suitable power level of the tractor during performing tillage operations.

The 47HP tractor realized higher value of efficiency in all the tested operations. Consequently it might be recommended as the more suitable power rating for the tested mechanized operations.

\section{REFERENCES}

Bamigboye, I. and Ojolo, S. (2002). Cost of Operating Farm Tractors. Moor Journal of Agricultural Research, Volume 3 No 2, pp229232.

Hadas, A. (1997). Soil tilth-the desired soil structural state obtained through proper soil fragmentation and reorientation processes. Soil \& Tillage Research, 43:7-40

Hanna, G. B. (1978). Prospects of farm mechanization on small holding in U. A. R. C. F. AMA, spring: 31-34.

Johnson, T.F. and Jose, M.R. (2011). Conservation tillage for cassava (Manihot esculenta crantz) production in the tropics. Soil Till. Res., 113:1-10

Nasr, G. M. (1985) Study of the optimum Tractor Power Requirement under Egyptian Agricultural Conditions, PHD. thesis, Agric. Eng., Fac. of Agric., Cairo Univ. 
Sahu, R.K. and Raheman, H. (2008). A decision support system on matching and field performance prediction of tractor-implement system. Computers and electronics in agriculture, 60:76-86

Sandeep Y. and S. Kumar . 2006. Tractor and Implement Ownership and Utilization of Haryana. Agricultural Mechanization in Asia, Africa and Latin America Vol. 37 No.3 pp 15-17.

Serrano, J.M.; Peca, J.O.; Marques da Silva, J.; Pinheiro, A. and Carvalho M. (2007). Tractor energy requirements in disc harrow systems. Biosystems Engineering, 98: 286 - 296

Smith, L.A. (1993). Energy requirements for selected crop production implements. Soil and Tillage Research, 25:281-299

Younis, S. M.(1995). Management of the farm machinery and power, Fac. of Agric., Cairo Univ.

\section{المخلص العربي}

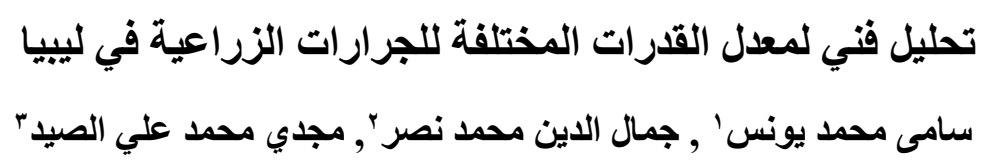

الهدف من هذه الدراسـة هو التوصل إلى القدرة المناسبة للجرار الزراعي في ظل الظروف

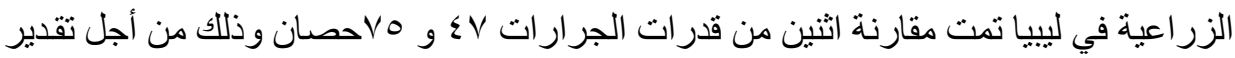

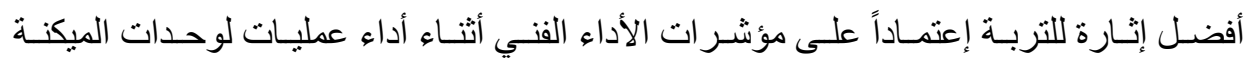
الزر اعية وهى معدل استهلاك الوقود ونسبة الانزلاق وقدرة السحب و الكفاءة الفعلية الحقلية

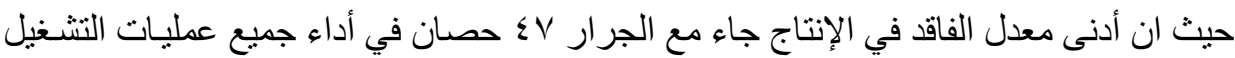

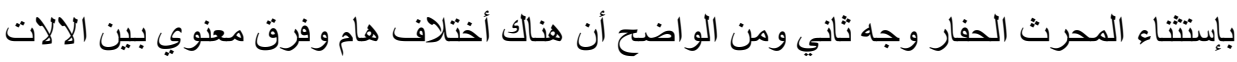

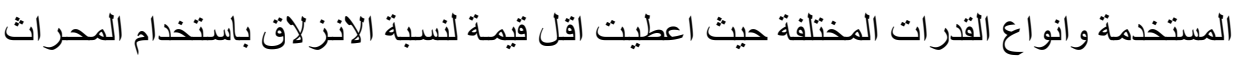

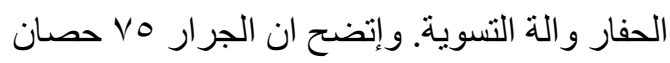

'أستاذ ـ قسم الهندسة الزراعية ـ كلية الزراعةــ جامعة القاهرة.

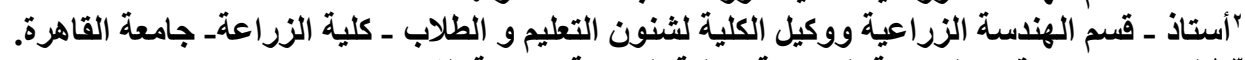
"طالب ماجيستير-قسم الهندسة الزراعية ـ كلية الزراعةـ جامعة القاهرة. 
بإستخدام الالات المختلفة سجل أعلى استهلاك للوقود (لتر /ساعة). كما ان هناك فرق معنوي في

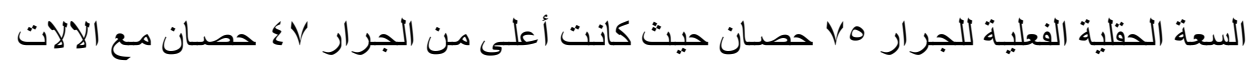

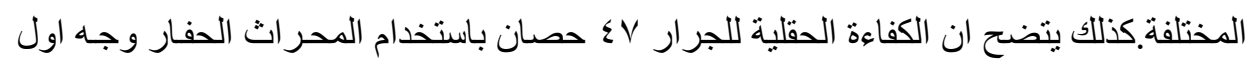
كانت اعلى من الكفاءة مع الالات الاخري. حقق الجرار قدرة Vo حصان مع المحراث الحفار وجه ثناني أعلى كفاءة حقلية مقارنـة بـالآلات

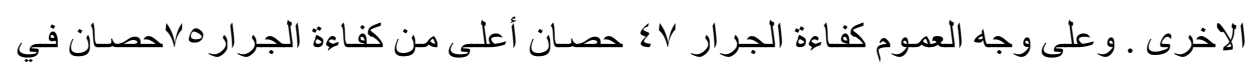
جميع العمليات المختبره وبالتالي يعتبر الانسب بالنسبة للعمليات الميكانيكية المختبره للإستخدام كمدر للقدرة الميكانيكية لأداء العمليات الحقلية في ليبيا. الكلمات الدالة: الجرارات الزر اعية و المحر اث المطرحي والمحراث الحفار والدحرات القرصي

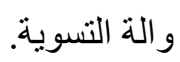

